UDK 632.51

Pregledni rad-Review paper

\title{
Worldwide complexity of weeds
}

\author{
Zvonko Pacanoski ${ }^{1}$, Arben Mehmeti $^{2}$ \\ ${ }^{1}$ Faculty for Agricultural Sciences and Food, Ss. Cyril and Methodius University, \\ Skopje, N. Macedonia \\ 2Faculty of Agriculture and Veterinary, University of Prishtina „Hasan Prishtina” \\ Prishtinë, Kosovo \\ e-mail: zvonkop@fznh.ukim.edu.mk
}

\begin{abstract}
SUMMARY
No more than $3 \%$ of the total plant species on the Earth account for weeds, but they cause significant problems to humankind by intruding in food security and safety, health, environment, economic stability, and welfare. The problem of weeds as a worldwide problem increases, as human activities and their interference with the environment are increasing. Weeds owing to their forceful and flexible nature, cause considerable losses in agriculture, forestry, aquaculture, water supply and a variety of other human enterprises. Overall, weed-crop competition is the most important cause reducing sustainable crop production. They decrease production due to competition, allelopathy, and by providing environment for pathogens, serving as alternate hosts for numerous insects and fungi, thus causing an increase in harvesting expenditures. Weeds are prominent yield reducers, often economically more significant than insects, pathogens or other biotic constrains altogether. Worldwide damages generated by weeds are responsible for a loss of $13.2 \%$ of crop yields, but the probable losses in agricultural production without weed control are predicted at $20-90 \%$ globally. Key words: weeds, control, damages, losses, costs.
\end{abstract}

\section{THE PARABLES OF THE WEEDS}

-To Adam he said, -"Because you listened to your wife and ate from the tree about which I commanded you, 'You must not eat it.'

"Cursed is the ground because of you; through painful toil you will eat of it all the days of your life. It will produce thorns and thistles for you, and you will eat the plants of the field.

Genesis 3:17-19, (Anonymous, 2011). 
${ }^{24}$ Jesus told them another parable: "The kingdom of heaven is like a man who sowed good seed in his field. ${ }^{25}$ But while everyone was sleeping, his enemy came and sowed weeds among the wheat, and went away. ${ }^{26}$ When the wheat sprouted and formed heads, then the weeds also appeared.

27 “'The owner's servants came to him and said, 'Sir, didn't you sow good seed in your field? Where then did the weeds come from?'

28 "'An enemy did this', he replied.

"The servants asked him, 'Do you want us to go and pull them up?'

29 '"No,' he answered, 'because while you are pulling the weeds, you may uproot the wheat with them. ${ }^{30}$ Let both grow together until the harvest. At that time I will tell the harvesters: First collect the weeds and tie them in bundles to be burned; then gather the wheat and bring it into my barn."'

Matthew 24-30, (Anonymous, 2011).

${ }^{36}$ Then he left the crowd and went into the house. His disciples came to him and said, "Explain to us the parable of the weeds in the field."

${ }^{37} \mathrm{He}$ answered, "The one who sowed the good seed is the Son of Man. ${ }^{38}$ The field is the world, and the good seed stands for the people of the kingdom. The weeds are the people of the evil one, ${ }^{39}$ and the enemy who sows them is the devil. The harvest is the end of the age, and the harvesters are angels.

40 "As the weeds are pulled up and burned in the fire, so it will be at the end of the age. ${ }^{41}$ The Son of Man will send out his angels, and they will weed out of his kingdom everything that causes sin and all who do evil. ${ }^{42}$ They will throw them into the blazing furnace, where there will be weeping and gnashing of teeth. ${ }^{43}$ Then the righteous will shine like the sun in the kingdom of their Father. Whoever has ears, let them hear.

Matthew 13:36-43, (Anonymous, 2011).

\section{WEEDS AS THE BIGGEST AGRICULTURAL PROBLEM}

Within the parallel accounts in Matthew, Mark, and Luke, weeds are defined as: The cares of this world, which one commentator calls "anxious, unrelaxing attention to the business of this life." Even Bible says that God had already created weeds on the Earth as a curse prior to the fall of Adam and Eve.

Weeds are one of the oldest (10.000-12.000 BC) (Hay, 1974; Avery, 2006) and still most significant problems (second after soil erosion) related mostly to agriculture (Zimdahl, 2007; Baucom and Holt, 2009). Because weeds are ubiquitous, there is an intention to see them as necessary, and one of the inevitable damages associated with farming (Dekker, 2011); subsequently no adequate, universal, and intensive force is being completed to overwhelm the huge loss which they generate (Harker, 2001; Oerke, 2006). So far the weed control is one 
of the regular practices on the farm, and it represents a great amount of the labour needed to generate crop yields.

From an anthropocentric point of view, weeds are defined as a particular group of plant species that are treated as obnoxious in specific given circumstances (Quasem and Foy, 2008). They vary in their nature and habitats all over the world. No more than $3 \%$ of the total plant species on the Earth account for weeds (Kostov, 2006), and they cause huge difficulties to humankind by disrupting food security and safety, health, environment, economic stability, and welfare (Sinden et al., 2004). Weeds consume environmental resources intensively (Silva and Silva, 2007; Radosevich et al., 2007). At same time they are troublesome, destructive, and extremely aggressive invaders, which emerge by themselves without being planted by growers, alerting energy to a route unwanted by man (Chandrasena, 2008).

Weeds as an agriculture matter would not be identified without human disturbance and obstruction of the environment (Holt, 1994). They did not present a problem in the stabilized natural ecosystems prior to the development of agriculture (Marwat et al., 2010). Therefore, humans have created weeds and are accountable to discover an answer to the problems they caused to agriculture, the environment, and human society, as a whole. Thus, weeds are as old as agriculture itself (Appleby, 2005) and developed significantly modified features which allow them to grow, flourish, occupy, and dominate essential pieces of the natural system (Singh et al., 2001). Additionally, weeds have coexisted with cultivated crops, in manners that mimic morphological characteristics of the cultivated crop, consequently making their control difficult (Harlan, 1995). In reality, most domesticated plants have developed one or more companion weed races (Harlan, 1992).

Weed-crop antagonism is the most important factor reducing sustainable crop production (Avery, 1997). Weeds owing to their forceful and flexible nature (Chauhan et al., 2017) cause considerable losses in agriculture (Oerke, 2006), forestry (Pimentel et al., 2000), aquaculture (Datta, 2009), water supply (Abouziena et al., 2014-2015) and a host of other human enterprises (Sinden et al., 2004). At a more sophisticated level, it is accepted that weeds are destructive, problematic, and competitive elements within croplands (Ramesh et al., 2017). They decrease production through competition (Khan et al., 2002; Olesen et al., 2004; Siddiqui et al., 2010; Pacanoski and Mehmeti, 2021), allelopathy (Gao et al., 2009; Bertholdsson, 2012; Zhang et al., 2016; Mousavian and Eskandari, 2018; Pacanoski and Mehmeti, 2019), and by providing environment for pathogens, serving as alternate hosts for numerous insects and fungi (Capinera, 2005), thus causing rising harvesting expenditures (Ozpinar, 2006). The health and welfare of peoples lives globally are affecting by weeds which generate health hazards (Handerson and Anderson, 1996), including allergies (Gadermaier et al., 2004) and intoxications (Binev et al., 2007; Jung et al., 2012; Kerchner and Farkas, 2020). Weeds share the same nutrient level with crop plants, and weed-crop antagonism for limited resources such as space (Maxwell and Luschei, 2004), light (Liu et al., 2009), water (Swanton et al., 2015), and nutrients, (Lehoczky and Reisinger, 2003) causes considerable and huge crop yield losses (Pacanoski, 2007; Swanton et al., 2015; Ramesh et al., 2017). Weeds are the reason for qualitative implicit losses, due to unitary seed reduction, seed contamination, reduction in tillage and harvesting practices 
(Anderson, 1983; Asthon and Monaco, 1991; Kostov, 2006), as well as weed capability to spread bad aromas or flavours to milk or dairy products (King, 1966).

\section{WORLDWIDE DAMAGES AND LOSSES CAUSED BY WEEDS}

Weeds are prominent yield reducers that are in numerous conditions economically more significant than insects, pathogens or other biotic constrains altogether (Savary et al., 1997; Savary et al., 2000). Weeds are not similar to other biotic agents because they cause problems in crop production quite frequently, whereas occurrences of insects and pathogens are periodic (Gianessi and Sankula, 2003). Crop loss and damages generated by weeds are "invisible" and are not as remarkable as those generated by other biotic agents (Labrada, 1996). Worldwide damages generated by weeds are culpable for a loss of $13.2 \%$ of crop yields (Oerke et al., 1994), but the probable losses in agricultural production without weed control are predicted to be 20 to $90 \%$ globally (Oerke, 2006; Gianessi and Williams, 2011; Rodenburg and Johnson, 2013). Rao (2000) has stated that weeds are responsible for $45 \%$, insects $30 \%$, diseases $20 \%$, and other pests $5 \%$ for the overall annual loss of agricultural production on a global scale. Losses are especially harmful in impoverished countries of the world, where climates are quite wet and warm, crops are grown throughout the year, as continuous crops, crop cultivars or land-races are vulnerable, and crop protection is lacking or of sporadic efficiency (Oerke, 2006). In the early 2000s, escalating weed infestation in the Ukraine agricultural system was recognized as one of the major problems generating serious crop yield losses (Borona et al., 2002). In the same period, in Kazakhstan, around 2.5 million ha of grain were severely infested with weeds (Lindeman, 2005). Crop fields in Asia have been incurring yield losses because of inadequate weeding. A 1991-1995 study of farmers' fields in tropical Asia revealed that uncontrolled weeds in rice fields was the most important biotic factor in compromising yields: weeds growing above the rice canopy decreased yields by $23 \%$ and weeds growing below the rice canopy reduced rice yields by $21 \%$ (Savary et al., 2000). In India, Behera and Singh (1999) reported that the yield of dry land crops was reduced by weeds between $37-79 \%$ and the usual tradition of manual weeding in addition to being effectiveness, has also turned costly and burdensome. In Bangladesh, due to inadequate weed control, the loss in rice yields in growers' fields has been constant, at a rate between 43-51\% (Rashid et al., 2012). Effects of appropriate herbicides use are evident in rice production in China. In 1973, weeds caused rice crop losses of $40 \%$, although the rice was hand-weeded several times. This situation changed in 1988, when wider acceptance of herbicides caused only 6-8\% losses of rice yield due to weeds (Moody, 1991). A 2010 study of a rice production zone of the Yunnan plateau demonstrated that uncontrolled weeds above the canopy of rice resulted in the current yield losses of $2.8 \%$, while uncontrolled weeds below the canopy caused only $1.5 \%$ yield loss (Dong et al., 2010). A report from Africa confirmed that $15 \%$ of the total rice production is lost annually as a result of weed infestations, which represent about 2.3 million tons of rice (Rodenburg and Demont, 2009). In addition, many weeds use nutrients more efficiently than crops. For 
example, in a South African experiment, fertilization of weedy maize literally increased yield losses generated by weeds by $62 \%$ (Benson, 1982). Studies by Banga et al. (2003), as well as Anjum and Bajwa (2010) confirmed that weed infestation is the major reason for low wheat yields in Pakistan and India, which decrease wheat production by $25-30 \%$. Chikoye et al. (2005) concluded that the average grain yield on growers' fields in Africa is still very low. In addition to other reasons, an important segment of the yield break is connected to inadequate crop management, particularly poor weed control. In West Africa, due to weed competition, the maize yield losses range between 50 and $90 \%$.

In traditional cropping systems, in some regions of Africa, weed competition in crops may be so serious that fields are completely abandoned after 3-4 seasons (CIRAD, 2012). In Malawi, an extensive study demonstrated that one-third of the maize land sowed by small holders is abandoned unweeded. As a result of weed competition in Zimbabwe, 21\% of cotton growers left more than $20 \%$ of their crops each year (Mavudzi et al., 2001). Koch (1992) anticipated that the quantity of food lost due to weed infestation, regardless of weed control, was $25 \%$ of possible agricultural production in the developing countries. The quantity of crop yield lost yearly due to weeds can run up to $30 \%$, leaving more than 800 million people in the world in food insecurity because of it. In other words, considerable crop losses due to weeds correspond to the quantity that might feed 2 billion more people globally over the next 40 years (Gianessi, 2013).

Weeds are the most severe constraint in crop production with a projected yearly worldwide damage of approximately 40 billion USD (Monaco et al., 2002) and an economic loss exceeding 100 billion USD (Appleby et al., 2001). In US crop production, weeds are projected to decrease yields by $12 \%$ per year, or roughly 36 billion $\$$ in lost income (USBC, 1998). Additionally, an extra 4 billion USD is spent annually on herbicides for weed control (Pimentel et al., 1999), and over 3 billion USD for other techniques of weed control. But, without herbicides, there would be an expected 13.3 billion USD loss in revenue (Anonymous, 2003). Yancy and Cecil (2005) estimated benefits of herbicide use at 21 billion USD yearly, in addition to 6.6 billion USD in expenditures for herbicide products and application, thus decreasing losses due to weeds by $23 \%$ and, in same time, decreasing losses of farm revenues by 8 billion USD. Bridges (1992) investigated losses caused by weeds in 46 crops in the US. The yearly economic loss in crops besides applying common Best Management Practices (BMP), including herbicides, was projected at 4.1 billion USD, and this expenditure enlarged to 19.6 billion USD, or a nearly 5 -fold increase if herbicides were not used. For all methods of weed control, around $82 \%$ of the economic loss emerged in field crops, $9 \%$ in vegetables, $8 \%$ in non-citrus and citrus fruit crops, and 1\% in tree nuts (Bridges, 1992). Projected expenses of controlling weeds in pastures and rangelands were 5 billion USD, in lawns, gardens, and golf courses 1.5 billion USD, and for aquatic situations 100 million USD (Pimentel et al., 1999). Pimentel et al., (2005) estimated that weeds cost the US economy 33 billion USD annually. An immense part of these costs is connected to the control of alien (invasive) plant species that have been introduced into the United States. Invasive species generate massive environmental damages and losses of nearly 120 billion USD annually (Pimentel et al., 2005). The total cost of weeds to Australian cereal 
farmers is anticipated to be 3.3 billion USD. Weeds are costing the Australian cereal farmers 146 USD per ha in costs and losses. Yield losses because of weeds are estimated at 2.76 million tons in cereal production (Llewellyn et al., 2016). The yearly loss of Russian grain production, as a result of weed competition during 1996-2000 period was projected to be 10.5 million tons (Zakharenko, 2004). In India, the total real monetary loss because of weeds in the 10 most important crops was expected to be nearly 11 billion USD (Gharde et al., 2018), and in Pakistan the economically most important weeds in cultivated lands generate an economic loss valued at 3 billion USD yearly (Matloob et al., 2020).

However, even after BMP, crop losses because of weeds in western Canada field crops are projected to overpass 0.5 billion USD yearly (Swanton et al., 1993). Approximately, yield loss caused by weeds in maize and soybean are $52 \%$ and $49.5 \%$, respectively when applying BMP, but without the use of herbicides. More than $50 \%$ of maize and soybean production and value across all of North America could probably be gone due to uncontrolled weeds. Mutual losses in maize and soybean crops could equal to 43 billion USD overall yearly in the U.S. and Canada (Soltani et al., 2016; Soltani et al., 2017). Hall et al. (1992) noted that if weeds were not controlled prior to the $\mathrm{BBCH} 13-14$ (3 to 4-leaf tip stage of maize), yield loss was significant and did not improve even if weeds were controlled latter in the season. Yield losses due to uncontrolled weeds during the critical period for weed control (BBCH 13-20) ranged from $0.3 \%$ to $2.2 \%$ per day. The study of Sikkema and Hamill (2005) has shown that a one day delay in herbicide application after the critical period for weed control in maize would result in a yield loss of $30 \mathrm{~kg} \mathrm{ha}^{-1}$. Hypothetically, if, as a consequence of weather conditions or workload limits, the application of herbicide was delayed by one week, this would result in a yield loss of $215 \mathrm{~kg} \mathrm{ha}^{-1}$. Higher yield losses should be expected in more competitive or stressful conditions, with identically bigger impacts on income per hectare. At one very competitive place, the same authors noted a maize yield loss of $200 \mathrm{~kg} \mathrm{ha}^{-1}$ per day. Similar, yield losses in soybean prior to the critical period for weed control were minimal. Upon reaching this period, the yield loss rose to an average $65 \mathrm{~kg} / \mathrm{ha}$ per day for every day that weed control was delayed from the BBCH $12-13$ (2 $2^{\text {nd }}$ to the $3^{\text {rd }}$ trifoliate stage).

\section{CONCLUSIONS}

Weeds impact everyone and should be a concern to all. They do not only decrease agricultural production and enhance the expenditure of its products, but they also generate problems for the community and society in many ways. Weeds are damaging natural ecosystems, such as native prairies, plains, wetlands, woods and forests, and other wildlife habitats surrounding farmlands. They are problematic in irrigation and drainage systems, along highways, waterways and railways and industrial areas. Weeds are so universal and frequent, that people do not fully understand their importance and complexity in terms of losses and control costs. Currently, many invasive and resistant weed species are increasing and these are influencing the expenditures of weeds control and crops yield. Additionally, some weed species generate 
dermatitis, hay fever and allergic reactions in humans. Moreover, weeds cause difficulties in recreational areas such as parks, golf courses, domestic gardens, and fishing and boating sites.

\section{REFERENCES}

Abouziena, H. F., El-Saeid, H. M., El-Said Amin, A. A.: Water loss by weeds: a review. International Journal of ChemTech Research, 7 (1), 323-336, 2014-2015.

Anderson, W. P.: Weed Science, Principles, Second edition. New York: West Publishers, 1983.

Anjum, T., Bajwa, R.: Competition losses caused by Rumex dentatus L. and Chenopodium album L. in wheat (Triticum aestivum L.). The Philippine Agriculture Scientist, 93 (3), 365-368, 2010.

Anonymous: Herbicide use essential to crop production, Chemical Market Reporter. 263 (18), p.4, 2003.

Appleby, A. P.: A history of weed control in the United States and Canada - a sequel. Weed Science, 53, 762-768, 2005. Appleby, A. P., Müller, F., Carpy, S.: Weed control. Ullmann's Encyclopedia of Industrial Chemistry. New York: Wiley-VCH Verlag GmbH and Co. KGA, 2001.

Ashton, F. M., Monaco, T. J.: Weed Science. Principles and Practices, third edition. UK: John Wiley and Sons Ltd., 1991.

Avery, A. A.: Nature's toxic tools: The organic myth of pesticide-free farming, Centre for Global food Issues. USA, Churchwille, 2006.

Avery, D. T.: Saving the planet with pesticides. Biotechnology, and European Farm Reform, In the Proceedings of the Brighton Crop Protection Conference - Weed, 1, 3-18, 1997.

Bagavathiannan, M. V., Graham, S., Ma, Z., Barney, J. N., Coutts, H. R., Caicedo, A. L.: Considering weed management as a social dilemma bridges individual and collective interests. Nature Plants, 5, 343-351, 2019.

Banga, R. S., Yadav, A., Malik, R. K.: Bioefficacy of flufecacet and sulfosulfuron alone and in combination againstweed flora in wheat. Indian Journal of Weed Science, 35 (3/4), 179-182, 2003.

Baucom, R. S., Holt, J. S.: Weeds of agricultural importance: bridging the gap between evolutionary ecology and crop and weed science. New Phytologist, 184, 741-743, 2009.

Benson, J. M.: Weeds in tropical crops: review of abstractson constraints in production caused by weeds in maize, rice, sorghum-millet, groundnuts and cassava. FAO Plant Production and Protection Paper, 32, Sup. 1, 1982.

Bertholdsson, N. O.: Allelopathy-A tool to improve the weed competitive ability of wheat with herbicide-resistant black-grass (Alopecurus myosuroides Huds.). Agronomy, 2, 284-294, 2012.

Binev, R., Mitev, J., Miteva, T.: Intoxication with poison hemlock (Conium maculatum L.) in calves. Trakia Journal Sciencies, 5, 40-50, 2007.

Blatchley, W. S.: The Idiana Weed Book. Indianapolis :The Nature publishing company. Holding Institution: University of California Libraries (archive.org), 1912.

Booth, B. D., Murphy, S. D., Swanton, C. J.: Weed Ecology in Natural and Agricultural Systems. CAB International, 2003.

Borona, V., Zadorozhny, V., Soroka, S., Ramaniuk, R., Hurle, K., Bulcke, R.: Integrated weed management methods for maize under the conditions of the forest-steppe zone of Ukraine and Byelorussia. $12^{\text {th }}$ European Weed Research Society Symposium, Wageningen: Netherlands, 2002.

Buchholtz, K. P.: Report of the terminology committee of the Weed Science Society of America. Weeds, 15, 388389, 1967.

Capinera, J. L.: Relationships between insect pests and weeds: An evolutionary perspective. Weed Science, 53 (6), 892-901, 2005.

Chandrasena, $N$.: Weeds and weed management under a changing climate. Conference: Biennial Conference of Indian Weed Science Society, 2008, At Patna, Bihar. Penrith: Australia, 2008.

Chauhan, B. S.: Grand challenges in weed management. Frontiers in Agronomy, 1, 1-4, 2020. 
Chauhan, B. S., Matloob, A., Mahajan, G., Aslam, F., Florentine, S. K., Jha, P.: Emerging challenges and opportunities for education and research in weed science. Frontiers in Plant Science, 8, 1537, 2017.

Chikoye, D., Udensi, U. E., Lum, A. F.: Evaluation of a new formulation of atrazine and metolachlor mixture for weed control in maize in Nigeria. Crop Protection, 24 (11), 1016-1020, 2005.

CIRAD: Annual report, Published on Sep 13, 2013, Agriculture, Sustainable development, Agroecology, 2012. https://agritrop.cirad.fr

Datta, S.: Aquatic weeds and their management for fisheries, 2009. https://www.researchgate.net/ publication/258931408.

Dekker, J.: Evolutionary ecology of weeds, 2011. http://agron-www.agron.iastate.edu/weeds/PDF_Library/ Agron_517/EEW_ClassUse_1.1.11.pd.

Dilipkumar, M., Chuah, T. S., Goh, S. S., Sahid, I.: Weed management issues, challenges, and opportunities in Malaysia. Crop Protection, 134, (2017) 104347. doi.org/10.1016/j.cropro.2017.08.027.

European Weed Research Society (EWRS): Constitution European Weed Research Society, p. 15, 1986.

Gadermaier, G., Dedic, A., Obermeyer, G., Frank, S., Himly, M., Ferreira, F. B: Biology of weed pollen allergens. Current Medicine Group, 4 (5), 391-400, 2004.

Gage, K. L., Krausz, R. F., Walters, S. A.: Emerging challenges for weed management in herbicide-resistant crops. Agriculture, 9 (180), 2-11, 2019.

Gao, X., Li, M., Gao, Z., Li, C., Sun, Z.: Allelopathic effects of Hemistepta lyrata on the germination and growth of wheat, sorghum, cucumber, rape, and radish seeds. Weed Biology and Management, 9, 243-249, 2009.

Gharde, Y., Singh, P. K., Dubey, R. P., Gupta, P. K.: Assessment of yield and economic losses in agriculture due to weeds in India. Crop Protection, 107, 12-18, 2018.

Gianessi, L., Williams, A.: Overlooking the obvious: The opportunity for herbicides in Africa. Outlooks on Pest Management. Research Information, 22 (5), 211-215, 2011.

Gianessi, L., Sankula, S.: The value of herbicides in U.S. crop production. National Centre for Food and Agriculture Policy (NCFAP), 2003. http://www.ncfap. org/documents/FullText.pdf.

Gianessi, L. P.: The increasing importance of herbicides in worldwide crop production. Pest Management Sciences, 69, 1099-1105, 2013.

Gill, M. T., Vear, K. C.: Agricultural Botany. Duckworth, London, 1958.

Gill, N., Graham, S., Cross, R., Taylor, E.: Weed hygiene practices in rural industries and public land management: variable knowledge, patchy implementation, inconsistent coordination. Journal of Environmental Management, 223, 140-149, 2018.

Hall, M., Swanton, C., Anderson, G.: The critical period of weed control in grain corn (Zea mays). Weed Science, 40, 441-447, 1992.

Handerson, M., Anderson, J. G.: Common weeds of South Africa memoirs of the botanical surveys of South Africa. N 37 Deptt. Agric, Tech., Svc Republic of South Africa, 1996.

Harker, K. N.: Survey of yield losses due to weeds in central Alberta. Canadian Journal of Plant Science, 81, 339-342, 2001.

Harlan, J. R.: Crops and man. Second edition. Madison, Wisconsin: American Society of Agronomy, Inc. Crop Science Society of America, Inc., 1992.

Harlan, J. R.: The living fields: our agricultural heritage. Cambridge, UK: Cambridge University Press, 1995.

Harper, J. L. (Ed.): The Biology of Weeds. Blackwell Scientific, Oxford, 1960.

Hay, J. R.: Gain to the grower from weed science. Weed Science, 22 (5), 439-442, 1974.

Holt, J.: Impact of weed control on weeds: new problems and research needs. Weed Technology, 8 (2), 400-402, 1994.

Humburg, N. E. (Ed.): Herbicide handbook, $6^{\text {th }}$ ed. Weed Sci. Soc. Am., Champaign, IL. p. 301, 1989.

Jung, L. S., Eckstein, R. L., Otte, A., Donath, T. W.: Above- and below-ground nutrient and alkaloid dynamics in Colchicum autumnale: Optimal mowing dates for population control or low hay toxicity. Weed Research, 52, 348-357, 2012. 
Jussaume, R., Ervin, D.: Understanding weed resistance as a wicked problem to improve weed management decisions. Weed Science, 64 (S1), 559-569, 2016.

Khan, I., Hassan, G., Marwat, K. B.: Efficacy of different herbicides for controlling weeds in wheat crop - II Weed dynamics and herbicides. Pakistan Journal of Weed Science and Research, 8, 41-47, 2002.

Kerchner, A., Farkas. Á.: Worldwide poisoning potential of Brugmansia and Datura. Forensic Toxicology, 38, 30-41, 2020.

King, J. L.: Weeds of the world-biology and control. London: Leonard Hill Books Ltd., 1966.

Klingman, C. G., Ashton, F. M., Nooedhoff, L. J.: Weed science: Principles and Practices. John Wiley and Soons, New York, 1975.

Koch, W.: Impact of weeds in developing countries. In the Proceedings of the First International Weed Control Congress. Melbourne: Weed Science Society of Victoria, pp. 127-133, 1992.

Kostov, T.: Herbology. The university press of the Republic of Macedonia, Skopje, p. 371, 2006.

Labrada, R.: Weed management status in developing countries. In the Proceedings of the Second International Weed Control Congress. Copenhagen, Danmark, pp. 579-589, 1996.

Lehoczky, E., Reisinge, R. P.: Study on the weed-crop competition for nutrients in maize. Communications in Agricultural and Applied Biological Sciences, 68 (4 A), 373-380, 2003.

Lindeman, M.: Kazakhstan wheat production: An overview, 2005. http://www.fas.usda.gov/pecad2/ highlights/2005/03/Kazakh_Ag/index.htm.

Liu, J. G., Mahoney, K. J., Sikkema, P. H., Swanton, C. J.: The importance of light quality in crop-weed competition. Weed Research, 49 (2), 217-224, 2009.

Llewellyn, R. S., Ronning, D., Clarke, M., Mayfield, A., Walker, S., Ouzman, J.: Impact of weeds on Australian grain production - The cost of weeds to Australian grain growers and the adoption of weed management and tillage practices. Grains Research and Development Corporation and the Commonwealth Scientific and Industrial Research Organisation, 2016. https://grdc.com.au/_data/assets/pdf_file/0027/75843/ grdc_weeds_review_r8.pdf.pdf

Marwat, K. B., Hashim, S., Ali, H.: Weed management: a case study from North-West Pakistan. Pakistan Journal of Botany. Special Issue (S.I. Ali Festschrift), 42, 341-353, 2010.

Mateen, A., Zhu, Q.: Weed detection in wheat crop using uav for precision agriculture. Pakistan Journal of Agriculture Science, 56 (3), 809-817, 2019.

Matloob, A., Safdar, M. E., Abbas, T., Aslam, F., Khaliq, A., Tanveer, A., Rehmane, A., Chadhar, A. R.: Challenges and prospects for weed management in Pakistan: A review. Crop Protection. Article 104724, 2020. doi.org/10.1016/j.cropro.2019.01.030.

Mavudzi, Z., Mashingaidze, A. B., Chivinge, O. A., Ellis-Jones, J., Riches, C.: Improving weed management in a cotton-maize system in the Zambezi Valley, Zimbabwe. The 2001 Brighton Crop Protection Conference, Weeds, 169-174, 2001. BCPC, Farnham, Surrey: UK.

Maxwell, B. D., Luschei, E.: The ecology of crop-weed Interactions. Journal of Crop Improvement, 11 (1-2), 137-151, 2004.

Monaco, T. J., Weller, S. C., Ashton, F. M.: Weed science principles and practices. 4 Ed. New York: John Wiley and Sons, 2002.

Moody, K.: Weed management in rice. In: D. Pimentel (Ed.). Handbook of Pest Management in Agriculture. Vol. 3. Boca Raton, Florida: CRC Press, pp. 301-328, 1991.

Mousavian, S., Eskandari, H.: Allelopathic effect of two medicinal plants on seed germination, seedling growth and grain production of purslane (Portulaca oleraceae L.) weed. Acta Agriculturae Slovenica, 111 (2), 293-301, 2018.

Oerke, E. C.: Crop losses to pests. Journal of Agriculture Science, 144, 31-43, 2006.

Oerke, E. C., Dehne, H. W., Schönbeck, F., Weber, A.: Crop production and crop protection: estimated losses in major food and cash crops. Amsterdam: Elsevier, 1994. doi.org/10.1016/C2009-0-00683-7. 
Olesen, J. E., Hansen, P. K., Berntsen, J., Christensen, S.: Simulation of above-ground suppression of competing species and competition tolerance in winter wheat varieties. Field Crops Research, 89, 263-280, 2004.

Ozpinar, S.: Effects of tillage systems on weed population and economics for winter wheat production under the Mediterranean dry land conditions. Soil and Tillage Research, 87 (1), 1-8, 2006.

Pacanoski, Z.: Influence of herbicides on weeds and yield components of barley crop. Herbologia, 8 (2), 41-49, 2007.

Pacanoski, Z., Mehmeti, A.: Allelopathic effect of Siberian iris (Iris sibirica) on the early growth of wild oat (Avena fatua) and Canada thistle (Cirsium arvense). Journal of Central European Agriculture, 20 (4), 1179-1187, 2019.

Pacanoski, Z., Mehmeti, A.: Efficacy and selectivity of PRE-em herbicides on dependence of soil types and precipitation in sunflower crop. Journal of Agricultural Science 1, XXXII, 100-110, 2021.

Pätzold, S., Hbirkou, C., Dicke, D., Gerhard, R., Welp, G.: Linking weed patterns with soil properties: a long-term case study. Precision Agriculture, 21, 569-588, 2020.

Pimentel, D., Harvey, C., Resosudarmo, P., Sinclair, K., Kurz, D., Mcnair, M., Crist, S., Shpritz, L., Fitton, L., Saffouri, R., Blair, R.: Environmental and economic costs of soil erosion and conservation benefits. Science, 267, 1117-1123, 1995.

Pimentel, D., Lach, L., Zuniga, R., Morrison, D.: Environmental and economic costs of non indigenous species in the United States. BioScience, 50 (1), 53-65, 2000.

Pimentel, D., Zuniga, R., Morrison, D.: Update on the environmental and economic costs associated with alieninvasive species in the United States. Ecological Economics, 52, 273-288, 2005.

Qasem, J. R.: Weed control in tomato (Solanum lycopersicum Mill.) by new biodegradable polypropylene sheets and other soil mulching materials. Pakistan Journal of Agriculture Science, 56 (4), 857-866, 2019.

Radosevich, S. R., Holt, J. S., Ghersa, C. M.: Ecology of weeds and invasive plants: relationship to agriculture and natural resource management ( $3^{\text {rd }}$ Ed.). Hoboken, USA: John Wiley and Sons, 2007.

Ramesh, K., Matloob, A., Aslam, F., Florentine, S. K., Chauhan, B. S.: Weeds in a changing climate: vulnerabilities, consequences, and implications for future weed management. Frontiers in Plant Science, 8, 95, 2017.

Rao, S.: Principles of weed science. 2. Ed. New York: Science Publishers, p. 526, 2000.

Rashid, M. H., Alam, M. M., Ladha, J. K.: Comparative efficacy of pretilachlor and hand weeding in managing weeds and improving the productivity and net income of wet-seeded rice in Bangladesh. Field Crops Research, 128, 17-26, 2012.

Rodenburg, J., Demont, M.: Potential of herbicide resistant rice technologies for sub-Saharan Africa, AgBioForum, $12(3 / 4), 313-325,2009$.

Salisbury, E. J.: Weeds and Aliens. N.N. Collins. St. Jame’s Place, London. p. 384, 1961.

Savary, S., Willocquet, L., Elazegui, F. A., Castilla, N. P., Teng, P. S.: Rice pest constraints in tropical Asia: quantification of yield losses due to rice pests in a range of production situations. Plant Diseases, 84, 357369,2000 .

Savary, S., Srivastava, R. K., Singh, H. M., Elazegui, F. A.: A characterisation of rice pests and quantification of yield losses in the rice-wheat system of India. Crop Protection, 16, 387-398, 1997.

Scavo, A., Mauromicale, G.: Review-Integrated weed management in herbaceous field crops. Agronomy, 10, 466, 2020. doi:10.3390/agronomy10040466.

Siddiqui, I., Bajwa, R., Huma, Z. E., Javaid, A.: Effect of six problematic weeds on growth and yield of wheat. Pakistan Journal of Botany, 42 (4), 2461-2471, 2010.

Silva, A. A., Silva, J. F.: Biologia de plantas daninhas, In: Tópicos em Manejo de Plantas Daninhas, Universidade Federal de Viçosa, Viçosa, Brazil, pp.17-61, 2007.

Sinden, J., Jones, R. L., Hester, S., Odom, D., Kalisch, C., James, R., Cacho, O.: The economic impact of weeds in Australia CRC for Australian weed management, 2004. http://smtp.auricht.com/dewnr/data/tech_series_8_ Sinden_etal_Eco_Impact.pdf

Singh, H. P., Batish, D. R., Kohli, R. K.: Allelopathy in agroecosystems. Journal of Crop Production, 4 (2), 1-41, 2001. 
Soltani, N., Dille, A. J., Burke, I. C., Everman, W. J., Vangessel, M. J., Davis, V. M., Sikkema, P. H.: Potential corn yield losses from weeds in North America. Weed Technology, 30, 979-984, 2016.

Soltani, N., Dille, A. J., Burke, I. C., Everman, W. J., Vangessel, M. J., Davis, V. M., Sikkema, P. H.: Perspectives on potential soybean yield losses from weeds in North America. Weed Technology, 31, 148-154, 2017.

Swanton, C. J., Harker, K. N., Anderson, R. L.: Crop losses due to weeds in Canada. Weed Technology, 7, 537542, 1993.

Swanton, C. J., Nkoa, R., Blackshaw, R. E.: Competition for water experimental methods for crop-weed competition studies. Weed Science, 63 (sp1), 2-11, 2015.

USBC.: U.S. Bureau of the census, statistical abstract of the United States, 1996. 200 th ed. Washington, DC, U.S. Government Printing Office, 1998.

Vencill, W. K. (Ed.): Herbicide handbook, $8^{\text {th }}$ Ed. Weed Science Society of America, Lawrence, KS. p. 493, 2002.

Wilson, R., Tucker, M., Hooker, N., Lejeune, J., Doohan, D.: Perceptions and beliefs about weed management: Perspectives of Ohio grain and produce farmers. Weed Technology, 22 (2), 339-350, 2008.

Yancy, J., Cecil, H.: Study touts herbicide benefits. Southeast Farm Press, 32 (11), 16, 2005.

Zakharenko, V.A.: Phytosanitary condition of agroecosystems and potential yield losses from harmful organisms in agriculture under conditions of Russia's multiform economy. Russian Agriculture Sciences, 5, 13-18, 2004.

Zhang, C., Hu, R., Huang, J., Huang, X., Shi, G., Li, Y., Yin, Y., Chen, Z.: Health effect of agricultural pesticide use in China: Implications for the development of GM crops. Scientific Reports, 6, 34918, 2016. https:// doi.org/10.1038/srep34918.

Zimdahl, R. L.: Fundamentals of weed science (Third edition). USA: Academic Press is an imprint of Elsevier, 2007.

\section{Korovi su kompleksan problem širom sveta}

\section{REZIME}

Više od 30\% ukupne svetske flore čine korovi, a u okviru tog fonda nalaze se vrste koje prave ozbiljne probleme u biljnoj proizvodnji i dobijanju zdravstveno bezbedne herane, štetno deluju na zdravlje ljudi, životnu sredinu, ekonomsku stabilnost i blagostanje društva. Problem korova kao globalni problem na planeti raste kako se povećavaju ljudske aktivnosti i uticaj čoveka na životnu sredinu. Korovi zahvaljujući biološko-ekološkim karakteristikama, koje im između ostalog obezbeđuje snažan kompetitivni potencijal, uzrokuju značajne štete i gubitke u poljoprivredi, šumarstvu, akvakulturi, vodosnabdevanju i nizu drugih ljudskih aktivnosti. Generalno, konkurencija između korova i useva je najvažniji uzrok pada prinosa u mnogim usevima. Naime štete nastaju kao rezultat fizičke (direktne tj. konkurencije za životni prostor) i fiziološke (indirektne tj. konkurencije za prirodne resurse) kompeticije, alelopatskih međuodnosa, zatim korovi su često primarni ili sekunadarni domaćini biljnim patogenima i štetočinama, i na kraju povećavaju troškove tokom žetve useva. Korovi su apsolutno ekonomski najštetnija grupa bioagenasa u biljnoj proizvodnji jer su permanentno prisutni za razliku od patogena i štetočina koje se periodično javljaju. Na globalnom nivou procenjeno je da korovi utiču na gubitke u prinosu useva od 13,2\%, a ukoliko se ne bi pristupalo njihovom suzbijanju procenjuje se da bi se ti gubici kretali od 20-90\%.

Ključne reči: korovi, štete, suzbijanje, gubici, troškovi. 